\title{
Glucokinase gene in gestational diabetes mellitus: population association study and molecular scanning
}

\author{
K.C.Chiu ${ }^{1}$, R.C.P.Go ${ }^{2}$,M.Aoki ${ }^{1}$, A.C. Riggs ${ }^{1}$, Y.Tanizawa ${ }^{1}$, R. T. Acton ${ }^{2,3,4}$, D.S.H.Bell ${ }^{4}$, R. L. Goldenberg ${ }^{5}$, \\ J.M. Roseman ${ }^{4}$, M. A.Permutt ${ }^{1}$ \\ ${ }^{1}$ Division of Endocrinology, Diabetes, and Metabolism, Department of Internal Medicine, \\ Washington University School of Medicine, St. Louis, Missouri, USA \\ ${ }^{2}$ Department of Epidemiology, School of Public Health, University of Alabama, Birmingham, Alabama, USA \\ ${ }^{3}$ Department of Microbiology, School of Medicine, University of Alabama, Birmingham, Alabama, USA \\ ${ }^{4}$ Department of Medicine, School of Medicine, University of Alabama, Birmingham, Alabama, USA \\ ${ }^{5}$ Obstetrics and Gynecology, School of Medicine, University of Alabama, Birmingham, Alabama, USA
}

Summary Mutations of the glucokinase gene result in early-onset familial Type 2 (non-insulin-dependent) diabetes mellitus, and several members of the mutant glucokinase kindreds were originally diagnosed as having gestational diabetes. This study examined the glucokinase gene in 270 American Black women, including 94 with gestational diabetes whose diabetes resolved after pregnancy (gestational diabetes only), 77 with gestational diabetes who developed Type 2 diabetes after pregnancy (overt diabetes), and 99 normal control subjects who were recruited during the peripartum period. Two simple sequence repeat polymorphisms flanking either end of the glucokinase gene were evaluated. No association was found between glucokinase alleles and gestational diabetes only or overt diabetes, after adjustment for multiple comparisons. To detect single base changes, all 11 exons and proximal islet and liver promoter regions were examined by polymerase chain reaction plus single-stranded conformational polymorphism analysis in 45 gestational diabetes only patients who had not yet developed
Type 2 diabetes. Nine coding region variants were identified: Ala ${ }^{11}(G C C)$ to $\operatorname{Thr}^{11}(A C C)$ in islet exon 1, and 8 variants either in untranslated regions or in the third base of a codon. Four variant sites were found in introns, but none in splicing consensus sequences. Analysis of the promoter regions revealed two common variants, $\mathrm{G} \rightarrow \mathrm{A}$ at islet $-30(24 \%)$, and $\mathrm{G} \rightarrow \mathrm{A}$ at liver $-258(42 \%)$. The frequencies of the promoter variants, determined by allele specific polymerase chain reaction analysis, did not differ among the three groups. Thus, no significant coding sequence glucokinase mutations were found in 90 alleles from 45 patients with gestational diabetes. Further studies will be required to rule out a minor role of the newly-described promoter region variants as susceptibility factors in this disorder. [Diabetologia (1994) 37: 104-110]

Key words Type 2 (non-insulin-dependent) diabetes mellitus, glucokinase, gestational diabetes, American Blacks, single-strand conformation polymorphism.
Glucokinase (E.C. 2.7.1.1), an enzyme which is expressed only in pancreatic islet beta cells and liver [1], has been proposed to be the glucose sensor and metabolic signal generator in pancreatic beta cells and hepatocytes [2]. Mutations in the glucokinase (GCK) gene [3-6] result in early-onset familial Type 2 (non-insulindependent) diabetes mellitus, yet the potential con-

Received: 6 May 1993

and in revised form: 3 August 1993

Corresponding author: M. Alan Permutt, M. D., Division of Endocrinology, Diabetes, and Metabolism, Washington University School of Medicine, 660 S.Euclid Ave., Box 8127, St.Louis, MO 63110, USA tribution of mutations in this gene to other subtypes of Type 2 diabetes has not been determined. In the earlyonset Type 2 diabetic patients, glucokinase abnormalities result in a defective glucose sensing mechanism which causes a secretory defect in the pancreatic beta cells $[7,8]$. Several women with mutant GCK were diagnosed during pregnancy $[7,8]$, thus raising the possibility that defects at this locus may be responsible for a major effect in the gestational diabetes.

Pregnancy is a diabetogenic state with decreased insulin sensitivity [9]. Studies with appropriately matched control and gestational diabetic subjects however, have failed to demonstrate a significant difference in insulin sensitivity [10]. Furthermore, gestational diabetes was noted only in individuals whose beta cells 
Table 1. Clinical characteristics of study population

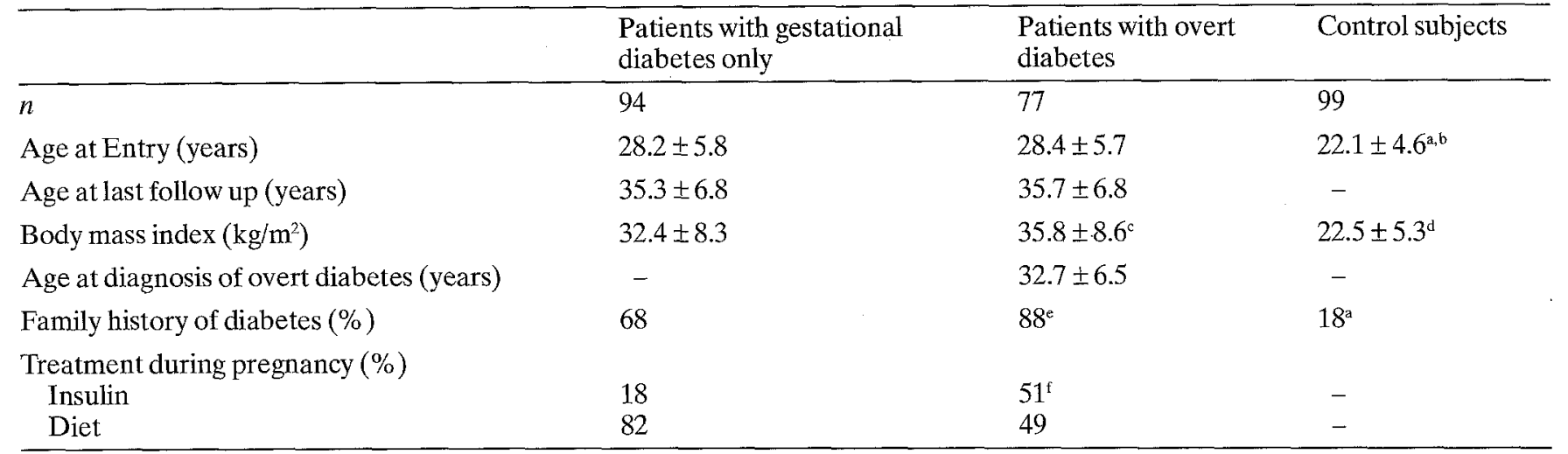

Values are given mean \pm SD.

${ }^{a}$ Gestational diabetes only vs control, $p=0.0001$

${ }^{\mathrm{b}}$ Overt diabetes vs control, $p=0.0001$

${ }^{c}$ Gestational diabetes only vs overt diabetes, $p=0.008$

failed to compensate for the insulin resistance of pregnancy. As beta-cell dysfunction appears to be important in gestational diabetes, and a genetic component is strongly suggested by family history [11], the glucokinase gene was considered a prime candidate gene for gestational diabetes.

In the present study, the glucokinase gene was surveyed in gestational diabetic patients by examining the association of two simple sequence repeat polymorphisms (SSRPs) which flank the $3^{\prime}$ - (GCK1) and $5^{\prime}$-ends (GCK2) of the gene $[12,13]$. The frequencies of alleles were determined among three groups, including gestational diabetic patients whose diabetes resolves after pregnancy (GDM only), gestational diabetic patients who developed Type 2 diabetes after pregnancy (overt diabetes), and control subjects. To more precisely define variations in the gene at the single nucleotide level, GCK was evaluated by polymerase chain reaction-single strand conformational polymorphism (PCR-SSCP) in 45 GDM only subjects.

\section{Subjects and methods}

\section{Study population and DNA extraction}

The cohort from which the subjects for this study were obtained comprised those who were seen for their first prenatal care visit at any of the eight Jefferson County (Alabama) Health Department Clinics between 1981 and 1992. Only American Blacks were recruited for the present study. Pregnant women with known history of Type 1 (insulin-dependent) or Type 2 diabetes or history of previous gestational diabetes were excluded from the present study. The details of the study protocol may be found in earlier reports $[14,15]$. Briefly, gestational diabetes was diagnosed based on the results of the oral glucose tolerance test (OGTT) according to the criteria of O'Sullivan and Mahan [16]. A subject diagnosed as having gestational diabetes was referred to the Division of Maternal and Fetal Medicine's Complications Clinic at the University of Alabama at Birmingham, where she was followedup for the duration of her pregnancy. Women were evaluated periodically after delivery up to a period of 10 years. Type 2 diabetes was based on diagnosis of a fasting blood glucose of more than

\footnotetext{
d Gestational diabetes only vs control, overt diabetes vs control, $p=0.0001$

${ }^{\mathrm{e}}$ Gestational diabetes only vs overt diabetes, $p=0.002$

${ }^{\mathrm{f}}$ Gestational diabetes only vs overt diabetes, $p=0.0001$
}

$7.8 \mathrm{mmol} / \mathrm{l}(140 \mathrm{mg} / \mathrm{dl})$ on two occasions or an abnormal OGTT according to the NationalDiabetes Data Group (NDDG) criteria [17] on the follow-up visits after delivery. At follow-up, subjects were evaluated with regard to height, weight, body mass index, personal and family history of diabetes. Those who had persistently elevated blood glucose and met the NDDG criteria on the follow-up visits after delivery were classified as having overt diabetes. Those patients who did not meet the NDDG criteria of diabetes at the follow-up visits after delivery were classified as GDMonly. Control subjects consisted of American Black women who presented and received prenatal care at the same clinic system but had no previous history of diabetes and whose screening tests for gestational diabetes were negative. The study was approved by the human studies committee of the University of Alabama at Birmingham School of Medicine and informed consent was obtained from each participant.

DNA was isolated from peripheral blood leucocytes [18]. A subsample (first 100 GDM only, first 80 overt diabetic, and first 100 control subjects) of DNA from a previous study [14,31] was selected for the present study. Duplicated samples were excluded from the analysis after GCK1 and GCK2 were typed. The first 45 GDM only subjects were examined by PCR-SSCP analysis. The clinical characteristics of the study population are shown in Table 1, and no other clinical data were available for the present study.

\section{Laboratory methods}

PCR assays for GCK1 [12] and GCK2 [13, 19] were the same as previously described. When necessary, DNA was analysed repeatedly or sequenced, or both so that each allele could be assigned unambiguously. To simplify the nomenclature of polymorphic markers, the alleles are designated as GCK1-1 to GCK1-7 corresponding to alleles, $Z, Z+2, Z+4, Z+8 ; Z+10$, $Z+12, Z-15$ at GCK1 locus [12] and GCK2-1 to GCK2-6 corresponding to alleles $0,2,4,6,-2,-4$ at GCK2 locus [13]. The data were not analysed until all the samples were typed at both GCK1 and GCK2 loci. Genotypic frequencies were calculated for each group and allelic frequencies were derived from the number of individual genotype.

Molecular scanning of 11 exons of GCK by PCR-SSCP was done as described previously [20]. Promoter regions $(-367$ to +68 in islet and -502 to +21 in liver) were scanned after amplification with primer sets (forward primer -390 to -367 and reverse primer -130 to -151 for islet distal promoter region; 
Table 2. Allelic frequency at GCK1 and GCK2 loci

\begin{tabular}{|c|c|c|c|c|c|c|}
\hline \multirow[b]{2}{*}{ GCK1 } & \multicolumn{2}{|c|}{$\begin{array}{l}\text { Patients with } \\
\text { gestational } \\
\text { diabetes only }\end{array}$} & \multicolumn{2}{|c|}{$\begin{array}{l}\text { Patients with } \\
\text { overt diabetes }\end{array}$} & \multicolumn{2}{|c|}{$\begin{array}{l}\text { Control } \\
\text { subjects }\end{array}$} \\
\hline & $n$ & $\%$ & $n$ & $\%$ & $n$ & $\%$ \\
\hline$\overline{\text { GCK1-1 }}$ & 107 & 56.91 & 90 & 58.44 & 119 & 60.10 \\
\hline GCK1-2 & 34 & 18.09 & 24 & 15.58 & 28 & 14.14 \\
\hline GCK1-3 & 31 & 16.49 & 17 & 11.04 & 33 & 16.67 \\
\hline GCK1-4 & 1 & 0.53 & 0 & - & 0 & - \\
\hline GCK1-5 & 13 & 6.91 & 20 & 12.99 & 18 & 9.09 \\
\hline GCK1-6 & 2 & 1.06 & 1 & 0.65 & 0 & - \\
\hline GCK1-7 & 0 & - & 2 & 1.30 & 0 & - \\
\hline Total & \multicolumn{2}{|l|}{188} & \multicolumn{2}{|l|}{154} & \multicolumn{2}{|l|}{198} \\
\hline \multicolumn{7}{|l|}{ GCK2 } \\
\hline GCK2-1 & 110 & 58.51 & 96 & 62.34 & 113 & 57.07 \\
\hline GCK2-2 & 45 & 23.94 & 44 & 28.57 & 58 & 29.29 \\
\hline GCK2-3 & 11 & 5.85 & 2 & $1.30^{\mathrm{a}}$ & 13 & 6.57 \\
\hline GCK2-4 & 2 & 1.06 & 1 & 0.65 & 1 & 0.51 \\
\hline GCK2-5 & 19 & 10.11 & 10 & 6.49 & 12 & 6.06 \\
\hline GCK2-6 & 1 & 0.53 & 1 & 0.65 & 1 & 0.51 \\
\hline Total & 188 & & 154 & & 198 & \\
\hline
\end{tabular}

When compared between overt diabetes and control groups: GCK2-3 vs non-GCK2-3: Yates' chi-square $=4.6699, p=0.031$

forward primer -177 to -154 and reverse primer 86 to 68 for islet proximal promoter region; forward primer -525 to -502 and reverse -201 to -223 for liver distal promoter region; and, forward primer -253 to -232 and reverse primer 41 to 21 for liver proximal promoter region, see [13] for nucleotide number). PCR was carried out as previously described [20], except for annealing at $70^{\circ} \mathrm{C}$ for islet and at $66^{\circ} \mathrm{C}$ for liver with $2 \mathrm{mmol} / 1$ $\mathrm{MgCl}_{2}$. For the polymorphic sites ( -30 at islet and -258 at liver), the study was extended to all the available samples. For islet -30 polymorphism, PCR was carried out as above without radioisotope, digested by Bsi HKAI (New England Biolabs, Beverly, Mass., USA) at $60^{\circ} \mathrm{C}$ for $3 \mathrm{~h}$, and then resolved on $2 \%$ agarose gel. The substitution of $\mathrm{G}$ with $\mathrm{A}$ abolished the Bsi HKAI site. Single nucleotide primer extension was used to type the liver -258 polymorphism. The cold PCR product was resolved on the $1 \%$ low-melting point (LMP) agarose and the corresponding band was cut out. One picomole of primer (forward primer -280 to -259 , see [13] for nucleotide number) was incubated with $2 \mu$ lof melted LMP agarose with template, $1 \mu \mathrm{Ci}$ of either $\alpha-{ }^{32}-\mathrm{P}-\mathrm{dGTP}$ for normal or $\alpha \mathrm{-}^{32} \mathrm{P}$-dATP for variant, $2 \mathrm{mmol} / 1 \mathrm{MgCl}_{2}, 10 \mathrm{mmol} / 1 \mathrm{Tr}$ is $\mathrm{HCl} \mathrm{pH} 8.3,50 \mathrm{mmol} / \mathrm{KCl}$, and $0.25 \mathrm{U}$ Taq DNA polymerase in a total volume of $10 \mu \mathrm{l}$. Samples were overlaid with mineral oil and processed through initial denaturing at $95^{\circ} \mathrm{C}$ for $5 \mathrm{~min}, 5$ cycles of denaturing at $95^{\circ} \mathrm{C}$ for $2 \mathrm{~min}$ and annealing-extension at $60^{\circ} \mathrm{C}$ for $2 \mathrm{~min}$. The products were denatured, resolved on a standard DNA sequencing gel, and processed for autoradiography [20].

\section{Statistical analysis}

Biostatistical analysis was performed as previously described $[19,21]$. Differences between groups with quantitative variables were evaluated by unpaired (two-tailed) Student's $t$-tests and differences in proportions were evaluated by chi-square test. The association of polymorphic alleles with Type 2 diabetes or gestational diabetes were analysed by $2 \times 2$ contingency tables. A Chi-square test of independence was performed with Yates' correction applied on Fisher's exact test where appropriate.
Odds ratios (OR) and $95 \%$ confidence intervals $(\mathrm{CI})$ were computed to assess the magnitudes of effect for individual genotype. The raw data (before Bonferroni correction [22] for multiple comparisons) were presented and the $p$ values were no longer significant after adjustment for multiple comparisons.

\section{Results}

\section{Frequencies of simple sequence repeat polymorphisms}

Allelic frequency at GCK1 is shown in Table 2. The allelic as well as genotypic frequencies did not differ among the three groups, in contrast to results in previous studies in American Blacks [19] and Mauritian Creoles $[19,21]$. Two new alleles (alleles GCK1-4 and GCK1-6) were identified at GCK1 in this population. GCK1-4 and GCK1-6 were 8 base pairs and 12 base pairs larger respectively than the most common allele (GCG1-1). The frequencies of these two alleles were relatively rare and homozygotes were not found. Although they occurred only in either the GDM only group (GCK1-4) or the group with overt diabetes (GCK1-6), no significant differences in frequency were found as compared to the control group.

At the GCK2 locus, only 6 alleles (Table 2 ) were identified in this population as compared to 8 alleles in the American Blacks studied at St. Louis (Tanizawa Y, Chiu KC, Permutt MA, unpublished observation). The frequency of the GCK2-3 allele in the overt diabetes group was less compared with the frequency in the control group $(1.30 \%$ vs $6.57 \%$ respectively, $p=0.031$ with Yates' correction). The difference was no longer significant after adjustment for multiple comparisons. Genotypic frequencies did not differ among the three groups. The genotypic frequencies of GCK1 and GCK2 observed in all three study groups did not differ from that predicted by Hardy-Weinberg equilibrium (data not shown).

\section{Molecular scanning of the coding region of the glucokinase gene}

Because Type 2 diabetes is a heterogeneous disease, population association studies have little power to detect mutations occurring in only a relatively small number of patients. To detect single base changes, the glucokinase gene was thus examined by PCR-SSCP analysis in 45 patients with GDM only. When variant SSCP patterns were detected on individual patients, genomic DNA was sequenced to determine the basis for the difference. Nine variants of the glucokinase gene were identified in this fashion (Table 3). Except for the $\mathrm{Ala}^{11}$ (GCC) to $\mathrm{Thr}^{11}$ (ACC) at nucleotide (NT) \# 517, the remainder of the variants occurred either in the 5 '-untranslated regions ( 2 in islet exon 1 and 1 in liver exon 1), or in the third base of a codon resulting in no amino acid change, and thus were without any obvious biological consequence. These variants were relatively rare, occurring in the heterozygous condition in less 
Table 3. Structural variants of glucokinase gene in the patients with gestational diabetes only

\begin{tabular}{|c|c|c|c|c|c|}
\hline Location & Nucleotide number & Common & Variant & Total $n=45$ & $\%$ \\
\hline \multicolumn{6}{|l|}{$\overline{\text { Exon }^{a}}$} \\
\hline Islet Exon 1 & $\begin{array}{l}220 \\
403 \\
517\end{array}$ & $\frac{\frac{G}{G}}{\underline{G} C C(\text { Ala } 11)}$ & $\begin{array}{l}\frac{\mathrm{T}}{\mathrm{C}} \\
\underline{\mathrm{A} C C}(\operatorname{Thr} 11)\end{array}$ & $\begin{array}{l}2 \\
2 \\
1\end{array}$ & $\begin{array}{l}4.44 \\
4.44 \\
2.22\end{array}$ \\
\hline Liver Exon 1 & 125 & $\underline{\mathrm{C}}$ & I & 2 & 4.44 \\
\hline Exon 3 & $\begin{array}{l}503 \\
623 \\
629\end{array}$ & $\begin{array}{l}\text { GTC }(\text { Val 70) } \\
\text { CCC (Pro 110) } \\
\text { GAC (Asp 112) }\end{array}$ & $\begin{array}{l}\text { GTT (Val 70) } \\
\text { CCI (Pro 110) } \\
\text { GAT (Asp 112) }\end{array}$ & $\begin{array}{l}1 \\
1 \\
1\end{array}$ & $\begin{array}{l}2.22 \\
2.22 \\
2.22\end{array}$ \\
\hline Exon 6 & $\begin{array}{l}935 \\
950\end{array}$ & $\begin{array}{l}\text { TAC } \underline{C}(\operatorname{Tyr} 214) \\
\text { TGE (Cys 219) }\end{array}$ & $\begin{array}{l}\text { TAT (Tyr 214) } \\
\text { TGI (Cys 219) }\end{array}$ & $\begin{array}{l}1 \\
1\end{array}$ & $\begin{array}{l}2.22 \\
2.22\end{array}$ \\
\hline Intron $^{\mathrm{b}}$ & & & Genotype & & \\
\hline Intron $1 \mathrm{~B}$ & -3 & & $\begin{array}{l}\mathrm{C} / \mathrm{C} \\
\mathrm{C} / \mathrm{T}\end{array}$ & $\begin{array}{r}44 \\
1\end{array}$ & $\begin{array}{r}97.78 \\
2.22\end{array}$ \\
\hline \multirow[t]{2}{*}{ Intron 3} & 19 & & $\begin{array}{l}\mathrm{G} / \mathrm{G} \\
\mathrm{G} / \mathrm{A}\end{array}$ & $\begin{array}{r}43 \\
2\end{array}$ & $\begin{array}{r}95.56 \\
4.44\end{array}$ \\
\hline & 21 & & $\begin{array}{l}\mathrm{G} / \mathrm{G} \\
\mathrm{G} / \mathrm{A}\end{array}$ & $\begin{array}{r}44 \\
1\end{array}$ & $\begin{array}{r}97.78 \\
2.22\end{array}$ \\
\hline Intron 9 & 8 & & $\begin{array}{l}\mathrm{C} / \mathrm{C} \\
\mathrm{C} / \mathrm{T} \\
\mathrm{T} / \mathrm{T}\end{array}$ & $\begin{array}{l}13 \\
20 \\
12\end{array}$ & $\begin{array}{l}28.89 \\
44.44 \\
26.67\end{array}$ \\
\hline
\end{tabular}

${ }^{a}$ For the amino acid and nucleotide numbering, see [5] for islet exon 1 and [7] for exons 3 and 6.

${ }^{\mathrm{b}}$ Partial sequence of introns $1 \mathrm{~B}, 3$, and 9:

(Intron 1B) tccectccetgtgcagGTAGAGCAGATCCT(Exon 2)

than $5 \%$ of individuals. As compared with our previous study [20], the variations at NT \# 99, 908, and 1124 were not found in this population and the nucleotide variations at NT \# 503, 623, and 935 were unique for this population.

\section{Molecular scanning of promoter regions of glucokinase gene}

Isolation of glucokinase cDNAs from liver [23] and islet [24] revealed that the $5^{\prime}$-ends were different. Characterization of genomic clones revealed that the proximal islet promoter was at least $20 \mathrm{~kb}$ upstream of the liver promoter region $[24,25]$. Regulation of expression of glucokinase differs in islets and liver, as insulin is the primary determinant of liver glucokinase mRNA levels [26], while islet glucokinase appears to be regulated more by plasma glucose levels [27]. To test the hypothesis that variants in the proximal promoter regions might alter the level of glucokinase in liver or islets or both, of GDM only patients, the PCR-SSCP screening analysis was extended to these regions.

A common polymorphism was found at position -30 in the islet promoter when 45 GDM only patients were examined. Since the polymorphic site was within a highly conserved region between the human and rat $[13,28]$, a PCR specific assay was developed, and the frequency of this islet promoter variant was determined in all the available samples. Genotypic and al-
(Exon 3) GGCACTGCTGAGATGgtgagcagcgcaggggccggggcagggggccaagg (Intron 3)

(Exon 9)TGCACCCA Ggtgagccegccccgc (Intron 9)

lelic frequencies were similar among three groups (Table 4). One rare variant was found at islet -321 .

A common polymorphism was also found in the liver promoter at -258 on examination of the 45 GDM only patients. Again, a PCR assay was developed and frequencies determined in all available subjects. As shown in Table 4, neither allelic or genotypic frequency of this liver promoter variant differed among the three groups. A variant in a single allele of one patient at -12 of the liver promoter was also found.

\section{Risk of diabetes by glucokinase genotype}

The risk of diabetes was assessed on each GCK1 and GCK2 allele as well as polymorphic sites at liver (258 ) and islet $(-30)$ promoter regions (Table 5). The risk, which was expressed as OR, was calculated from the frequencies of the gestational diabetic subjects with and without overt diabetes who carried a particular allele. These frequencies were derived from the genotypic frequencies.

As compared against the control group, GCK2-3 allele was a negative risk factor for overt diabetes $(p=0.01)$ and no other risk factor was identified for gestational diabetes at the other GCK loci. When the comparison was done between overt diabetes and GDM only groups, GCK1-5 allele was a positive risk factor for overt diabetes $(p=0.05)$ and GCK2-3 allele was a negative risk factor for overt diabetes $(p=0.03)$. 
Table 4. Promoter variants of glucokinase gene in the subject groups

\begin{tabular}{|c|c|c|c|c|c|c|c|c|}
\hline \multirow[t]{2}{*}{ Location } & \multirow[t]{2}{*}{$\begin{array}{l}\text { Nucleotide } \\
\text { Number }^{\mathrm{a}}\end{array}$} & \multirow[t]{2}{*}{ Genotype } & \multicolumn{2}{|c|}{$\begin{array}{l}\text { Patients with gestational } \\
\text { diabetes only }\end{array}$} & \multicolumn{2}{|c|}{ Patients with overt diabetes } & \multicolumn{2}{|c|}{ Control subjects } \\
\hline & & & $n$ & $\%$ & $\mathrm{n}$ & $\%$ & $\mathrm{n}$ & $\%$ \\
\hline \multirow[t]{2}{*}{ Islet Promoter } & -30 & $\begin{array}{l}\mathrm{G} / \mathrm{G} \\
\mathrm{G} / \mathrm{A} \\
\mathrm{A} / \mathrm{A}\end{array}$ & $\begin{array}{r}56 \\
37 \\
4\end{array}$ & $\begin{array}{r}57.14 \\
37.76 \\
4.08\end{array}$ & $\begin{array}{r}50 \\
26 \\
1\end{array}$ & $\begin{array}{r}64.94 \\
33.77 \\
1.30\end{array}$ & $\begin{array}{r}63 \\
34 \\
2\end{array}$ & $\begin{array}{r}63.64 \\
34.34 \\
2.02\end{array}$ \\
\hline & -321 & $\begin{array}{l}\mathrm{G} / \mathrm{G} \\
\mathrm{G} / \mathrm{A}\end{array}$ & $\begin{array}{r}44 \\
1\end{array}$ & $\begin{array}{r}97.78 \\
2.22\end{array}$ & & & & \\
\hline \multirow[t]{2}{*}{ Liver Promoter } & -12 & $\begin{array}{l}\mathrm{G} / \mathrm{G} \\
\mathrm{G} / \mathrm{A}\end{array}$ & $\begin{array}{r}44 \\
1\end{array}$ & $\begin{array}{r}97.78 \\
2.22\end{array}$ & & & & \\
\hline & -258 & $\begin{array}{l}\mathrm{G} / \mathrm{G} \\
\mathrm{G} / \mathrm{A} \\
\mathrm{A} / \mathrm{A}\end{array}$ & $\begin{array}{l}42 \\
36 \\
14\end{array}$ & $\begin{array}{l}45.65 \\
39.13 \\
15.22\end{array}$ & $\begin{array}{r}35 \\
35 \\
7\end{array}$ & $\begin{array}{r}45.45 \\
45.45 \\
9.09\end{array}$ & $\begin{array}{r}41 \\
49 \\
9\end{array}$ & $\begin{array}{r}41.41 \\
49.49 \\
9.09\end{array}$ \\
\hline
\end{tabular}

${ }^{a}$ For the nucleotide numbering, see [5]

Table 5. Risk of diabetes by glucokinase genotype

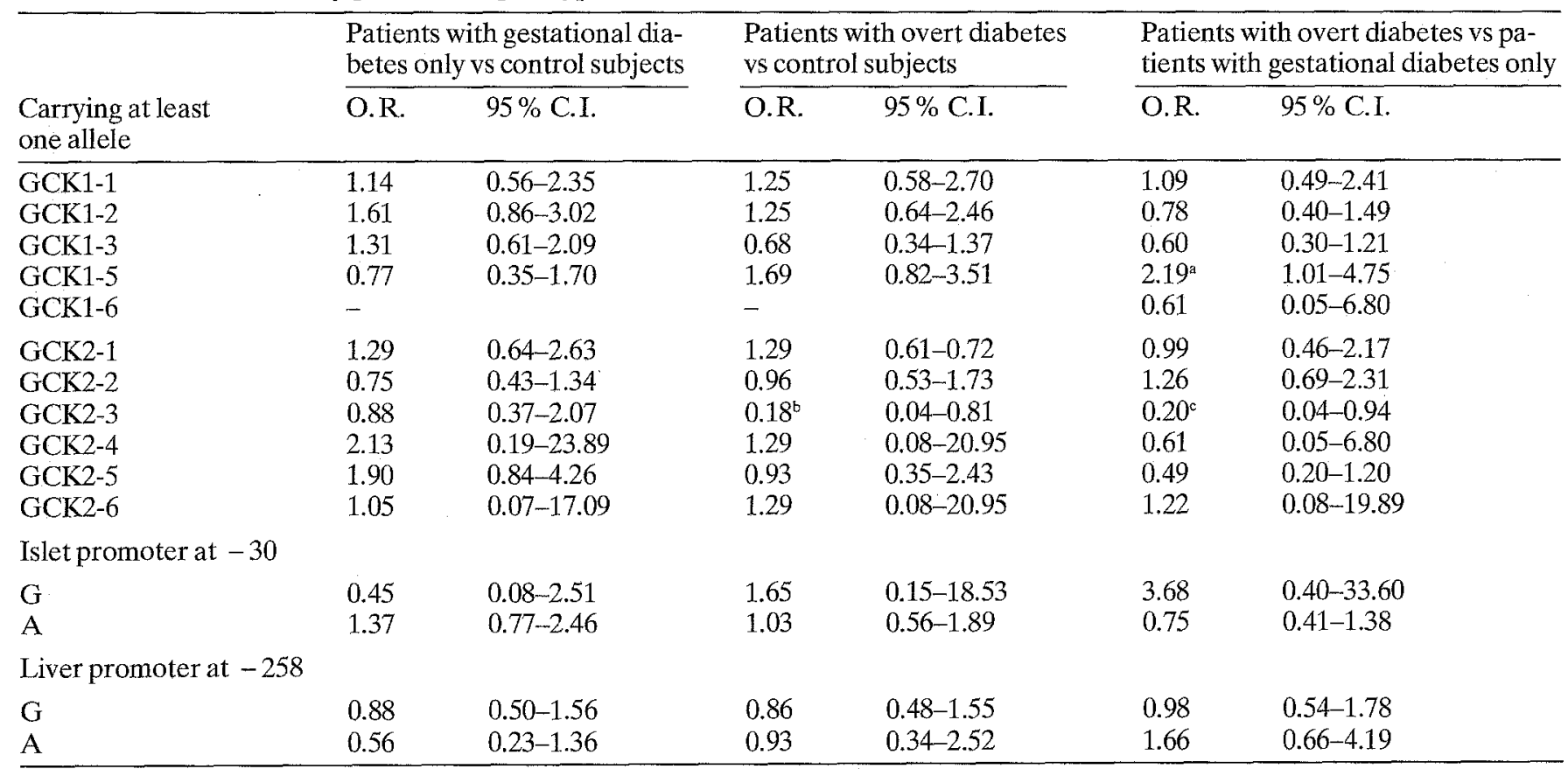

${ }^{\mathrm{a}} p=0.05 ;{ }^{\mathrm{b}} p=0.01 ;{ }^{\mathrm{c}} p=0.03$

$\mathrm{OR}$, Odds ratio; $\mathrm{CI}$, confidence interval

The significance of GCK1-5 for overt diabetes was unclear, since no difference was found when compared between the overt diabetes and control groups. Again, the differences were no longer significant after adjustment for multiple comparisons.

Adjustment for multiple comparisons ensures that the null hypothesis will not be mistakenly rejected regarding any given pair of variables if in reality that null hypothesis is correct. Unfortunately, the cost is to increase the frequency of incorrect statements that assert no relation between two factors, an error that can occur when an association in the data is not the result of chance. Therefore, the adjustment for multiple comparisons might be too conservative [29]. An alternative to the adjustment for multiple comparisons is to con- sider the information on all markers at a single gene simultaneously by comparison of patient and control groups for haplotype frequencies rather than allelic frequencies [30]. Using this approach, the information on all markers is utilized in a biologically relevant manner and the number of tests is reduced to the number of candidate genes being considered. However, in the case of SSRPs such as GCK1 ( 7 alleles) and GCK2 (6 alleles), multiple alleles at each locus result in a relatively large number of haplotypes (42 haplotypes, in contrast to 4 haplotypes in the case of the restriction fragment length polymorphism with 2 alleles for each marker) and less homozygotes at each locus can be counted due to relatively high heterozygosity $[12,13]$. This approach becomes less practical in the case of SSRPs and re- 
quires much larger sample sizes. Thus, the conservative interpretation is that there are no differences in GCK1 and GCK 2 frequencies among the groups.

\section{Discussion}

The most important aspect of an association study is the proper selection of patient and control groups [30]. In the present study, two groups (GDM only and overt diabetes) were properly matched by age of entry and last follow-up and by body mass index, they were ethnically the same group, and all study subjects were recruited from the same clinic system in one location (Jefferson County, Alabama). When compared with the GDM only group, a higher percentage of patients in the overt diabetes groups had family history of diabetes $(88 \%$ vs $68 \%, p=0.002)$, which suggested that a genetic factor was less important in the GDM only groups. And, $70 \%$ of subjects who received insulin treatment during the pregnancy developed overt diabetes, while only $33 \%$ of patients who received diet treatment developed overt diabetes $(p=0.0001)$. Although the control subjects were matched for race and attended the same clinics, they were evaluated only after delivery. After correction for multiple comparisons, no significant risk factor for diabetes was identified at glucokinase gene locus. In an immunogenetic study of this population, the prevalence of mitochondrial, smooth muscle, thyroid microsomal, parietal, nuclear, and islet cell autoantibodies was not found to differ significantly between GDM only and overt diabetes [31]. However, a stepwise regression analysis revealed that DR2 was an independent predictor of overt diabetes in this population [31].

In order to exclude the possibility of a minor role for the glucokinase gene in gestational diabetes, all 11 exons and proximal islet and liver promoter regions were examined by PCR-SSCP analysis in 45 GDM only patients. Only one structural mutation $\left(\mathrm{Ala}^{11} \rightarrow \mathrm{Thr}^{11}\right)$ was found in the coding region of 90 alleles from 45 GDM patients. Among the 15 amino acids in exon 1 , $\mathrm{Ala}^{11}$ is the only amino acid which is not conserved between human and rat $[20,24,25,28]$, and it is $\mathrm{Thr}^{11}$ in the rat $[20,25,28]$. The same frequency of $\operatorname{Thr}^{11}$ was found in the Type 2 diabetes and control groups in our previous study [20], so it is not likely that this amino acid variation has any biological consequence. The contributions of the PCR-SSCP variants observed in the two promoter regions to expression of glucokinase, and hence to susceptibility to gestational diabetes, are more difficult to interpret. Interestingly, the $G \rightarrow A$ variation at position -30 in the islet promoter is within the longest fragment ( 26 base pair) of homology between human $(-25$ to $-50,[13])$ and rat $(-52$ to -78 , $[20,25,28])$ glucokinase genes. The very high conservation of this portion of the promoters over 75 million years of evolution suggests the possibility of functional and/or structural importance of this 26 base pair frag- ment. Furthermore, a block transversion mutation between -51 to -60 in the rat islet promoteryields a $22 \%$ decrease in the promoter activity [32]. The $\mathrm{G} \rightarrow \mathrm{A}$ variation at -258 position in the liver promoter is within a completely conserved 10 base pair fragment between human $(-252$ to $-262,[13])$ and rat $(-136$ to -145 , [33]). This fragment is highly homologous to an insulin regulatory element in the phosphoenolpyruvate carboxykinase gene [34]. Therefore, we extended the analysis to determine the frequencies in all the samples available and found similar frequencies among three groups. The sample size examined was small, however, relative to what may be needed to detect minor susceptibility factors in polygenic diseases. A similar PCRSSCP analysis of the angiotensinogen gene in a population of hypertensive patients required a study of $499 \mathrm{pa}-$ tients and 238 control subjects to demonstrate a highly significant role of variants of this gene in susceptibility to hypertension [35].

Under only two electrophorectic conditions and using regular acrylamide, the optimal fragment for PCR-SSCP analysis is about 150 base pair [36] and it is not $100 \%$ sensitive. The fragment sizes in this study were larger than 150 base pair, however by using mutation detection enhancement gel (A.T.Biochem, Malvern, $\mathrm{Pa}$., USA) and by examining under multiple electrophoretic conditions we are able to detect the known glucokinase mutations which are not found in this population [20]. The sensitivity of current PCR-SSCP analysis to detect the single base pair change has been assessed $[20,37,38]$, it was not likely that the current study failed to detect existing mutations. However, the possibility of deletion, translocation, or a mutation which affects PCR in only one allele cannot be excluded with any known technique with $100 \%$ confidence and, in our previous study these possibilities have been excluded by Southern blot technique [20]. Very recently, glucokinase mutations were found in Caucasian and Hispanic women with gestational diabetes, but not in American Black women [39]. It suggests that structural defect of glucokinase is relatively rare in American Blacks as compared with other ethnic groups. No obvious coding or promoter mutation was found in examination of 90 glucokinase alleles from patients with GDM only. In conclusion, the results of this study indicate that, while some of the promoter variants may be minor susceptibility factors, the glucokinase gene does not play a major role in the pathogenesis of gestational diabetes or Type 2 diabetes in American Black women.

Acknowledgements. This work was supported in part by $\mathrm{Na}$ tional Institutes of Health Grants DK-07120 (K.C.C.), DK16746 (M.A.P.), DK-32767 (B.S.H.B., R.C.G., J.M.R., R.C.P.G and R.T.A.), DK-20575 (Diabetic Research and Training Center, Washington University) and RR-00036 (General Clinical Research Center, Washington University). A.M. was the recipient of a mentor-based Fellowship Award from the American Diabetes Association. Manuscript preparation by Ms. J. Wokurka is also gratefully acknowledged. 


\section{References}

1. Iynedijan PB, Mobius G, Seitz HJ, Wollheim CB, Renold AE (1986) Tissue specific expression of glucokinase: identification of the gene product in liver and pancreatic islet. Proc Natl Acad Sci USA 83: 1998-2001

2. Matschinsky FM (1990) Glucokinase as glucose sensor and metabolic signal generator in pancreatic $\beta$-cells and hetatocytes. Diabetes 39: 647-652

3. Vionnet N, Stoffel M, Takeda J et al. (1992) Nonsense mutation in the glucokinase gene cause early-onset non-insulindependent diabetes mellitus. Nature 356: 721-722

4. Stoffel M, Patel P, Lo Y-MD et al. (1992) Missense glucokinase mutation in maturity-onset diabetes of the young and mutation screening in late-onset diabetes. Nature Genetics 2: $153-156$

5. Froguel P, Zouali H, Vionnet $\mathrm{N}$ et al. (1993) Familial hyperglycemia due to mutation in glucokinase. New Engl J Med 328: 697-702

6. Gidh-Jain M, Takeda J, Xu LZ, Lange AJ, Vionney N, Stoffel M, Froguel P et al. (1993) Glucokinase mutations associated with non-insulin-dependent (type 2) diabetes mellitus have decreased enzymatic activity: implications for structure/function relationships. Pro Natl Acad Sci USA 90: 1932-1936

7. Hattersley AT, Turner RC, Permutt MA et al. (1992) Linkage of type 2 diabetes to the glucokinase gene. Lancet 339 : $1307-1310$

8. Velho G, Froguel P, Clement K et al. (1992) Primary pancreatic beta-cell secretory defect caused by mutation in glucokinase gene in kindreds of maturity onset diabetes of the young. Lancet 340: $444-448$

9. Cousins L, Rigg L, Hollingsworth D, Brink G, Aurand J, Yen SSC (1980) The 24-hour excursions and diurnal rhythm of glucose, insulin, and C-peptide in normal pregnancy. Am J Obstet Gynecol 136: 483-488

10. Cousins L (1991) Insulin sensitivity in pregnancy. Diabetes 40 [Suppl 2]: 39-41

11. Piscitelli J, Eden RD, Jelovsek FK, Grandis AS, Gall SA (1987) Family history of diabetes mellitus and oral glucose tolerance test criteria. Acta Obstet Gynecol Scand 66:489-492

12. Matsutani A, Janssen R, Donis-Keller H, Permutt MA (1992) A polymorphic (CA) repeat element maps the human glucokinase GCK (E.C. 2.7.1.1.) gene to chromosome 7p. Genomics 12:319-325

13. Tanizawa Y, Matsutani A, Chiu KC, Permutt MA (1992) Human glucokinase gene: isolation, structural characterization, and identification of a microsatellite repeat polymorphism. Molec Endocrinol 6: 1070-1081

14. Acton RT, Vanichanan CJ, Perkins L et al. (1990) Immunogenetic predictors of gestational diabetes in American Blacks. In: Andreani D, Bompiaini GD, Di Mario U, Faulk WP, Galluzzo A (ed) Immunobiology of normal and diabetic pregnancy, John Wiley \& Sons Ltd, New York, New York

15. Roseman JM, Go RPC, Perkins LL et al. (1991) Gestational diabetes mellitus among African-American Women. Diabetes Metab Rev 7: 93-104

16. O'Sullivan JB, Mahan CM (1964) Criteria for the oral glucose tolerance test in pregnancy. Diabetes 13:278-285

17. National Diabetes Data Group (1979) Classification and diagnosis of diabetes and other categories of glucose intolerance. Diabetes 28: 1039-1057

18. Kunkel LM, Smith RD, Soyer SH et al. (1977) Analysis of human Y chromosome specific reiterated DNA in chromosome variants. Proc Natl Acad Sci 74: 1245-1249

19. Chiu KC, Province MA, Permutt MA (1992) Glucokinase gene is genetic marker for NIDDM in American Blacks. Diabetes 41: 843-849
20. Chiu KC, Tanizawa Y, Permutt MA (1993) Glucokinase variants in the common form of NIDDM. Diabetes 42: 579-582

21. Chiu KC, Province MA, Dowse GK et al. (1992) A genetic marker at the glucokinase gene locus for type 2 (non-insulindependent) diabetes mellitus in Mauritian Creoles. Diabetologia 35: 632-638

22. Tukey J (1977) Some thoughts on clinical trials, especially problems of multiplicity. Science 198: 679-684

23. Tanizawa Y, Koranyi LI, Welling C, Permutt MA (1991) Human liver glucokinase gene: cloning and sequence determination of two alternative spliced cDNAs. Proc Natl Acad Sci USA 88: 7294-7297

24. Koranyi L, Tanizawa Y, Welling C, Rabin DU, Permutt MA (1992) Human glucokinase gene: isolation and sequence analysis of a full length islet cDNA. Diabetes 41: 807-811

25. Magnuson MA, Shelton KD (1989) An alternative promoter in the glucokinase gene is active in the pancreatic $\beta$-cell. $\mathbf{J}$ Biol Chem 264: 15936-15942

26. Iynedjian PB, Gjinovci A, Renold AE (1988) Stimulation by insulin of glucokinase gene transcription in liver of diabetic rats. J Biol Chem 263: 740-744

27. Iynedjian PB, Pilot P-R, Nouspikel T, Milburn JL, Quaade C, Hughes S et al. (1989) Differential expression and regulation of the glucokinase gene in liver and islet of Langerhans. Proc Natl Acad Sci 86: 7838-7842

28. Magnuson MA, Shelton KD (1989) An alternative promoter in the glucokinase gene is active in the pancreatic $\beta$-cell. J Biol Chem 264: 15936-15942

29. Rothman KJ (1990) No adjustments are needed for multiple comparison. Epidemiology 1: 43-46

30. Cox NJ, Bell GI (1989) Disease associations: chance, artifact, or susceptibility genes? Diabetes 38: 947-950

31. Acton RT, Roseman J, Bell D et al. (1993) Association of HLA-DR2 and autoantibodies with gestational and noninsulin-dependent diabetes in African American women. In: American Diabetes Association Research Symposium, 12th International Immunology and Diabetes Workshop. American Diabetes Association, Alexandria, Virginia, USA, p 52

32. Shelton KD, Franklin AJ, Khoor A, Beechem J, Magnuson MA (1992) Multiple elements in the upstream glucokinase promoter contribute to transcription in insulinoma cells. Molec Cell Biol 12: 4578-4589

33. Magnuson MA, Andreone TL, Printz RL, Koch S, Granner DK (1989) Rat glucokinase gene: structure and regulation by insulin. Proc Natl Acad Sci USA 86: $4838-4842$

34. O'Brien RM, Lucas PC, Forest CD, Magnuson MA, Granner DK (1990) Identification of a sequence in the PEPCK gene that mediates a negative effect of insulin on transcription. Science 249: 533-537

35. Jeunemaitre X, Soubrier F, Koteletsev YV, Lifton RP, Williams CS, Charru A, et al. (1992) Molecular basis of human hypertension: role of angiotensigen. Cell 71: 169-180

36. Sheffield VC, Beck JS, Kwitek AE, Sandstrom DW, Stone EM (1993) The sensitivity of single-strain conformation polymorphism analysis for the detection of single base substitutions. Genomics 16: 325-332

37. Olansky L, Janssen R, Welling C, Permutt MA (1992) Variation of the insulin gene in American Blacks with NIDDM. Diabetes 41: 742-749

38. Olansky L, Welling C, Giddings S, Adler S, Bourey R, Dowse $\mathrm{G}$ et al. (1992) A variant insulin promoter in non-insulin-dependent diabetes mellitus. J Clin Invest 89:1596-1602

39. Stoffel M, Bell KL, Blackburn CL, Powell KL, Seo TS, Takeda $J$ et al (1993) Identification of glucokinase mutations in subjects with gestational diabetes mellitus. Diabetes 42: 937-940 